\section{Comparison of Pallet Cover Systems to Maintain Strawberry Fruit Quality During Transport}

\author{
Andrew J. Macnish ${ }^{1,4}$, Malkeet S. Padda ${ }^{1}$, Francine Pupin ${ }^{1}$, \\ Pavlos I. Tsouvaltzis ${ }^{2}$, Angelos I. Deltsidis ${ }^{2}$, Charles A. Sims ${ }^{3}$, \\ Jeffrey K. Brecht ${ }^{2}$, and Elizabeth J. Mitcham ${ }^{1}$
}

AdDITIONAL INDEX wORDs. $\mathrm{CO}_{2}$, decay, Fragaria $\times$ ananassa, modified atmosphere, packaging, postharvest, temperature, truck, weight loss

SUMMARY. The efficacy of several proprietary plastic pallet cover systems to maintain strawberry (Fragaria $\times$ ananassa) fruit quality during commercial shipment was determined. 'Albion' fruit were harvested from farms near Watsonville, CA. Fruit in vented plastic clamshells were palletized and forced-air cooled to $33-35{ }^{\circ} \mathrm{F}$.

Different cover systems $\left(\mathrm{CO}_{2}\right.$ West, PEAKfresh, PrimePro, Tectrol) were placed over the pallets. Pads that released carbon dioxide $\left(\mathrm{CO}_{2}\right)$ gas were placed inside the $\mathrm{CO}_{2}$ West cover. The Tectrol cover was sealed to the pallet base, a partial vacuum was applied, and pressurized $\mathrm{CO}_{2}$ gas was injected inside. The systems other than Tectrol remained open at the base. Six separate shipments of palletized fruit were transported in refrigerated $\left(32-39^{\circ} \mathrm{F}\right)$ truck trailers to distribution centers in either Florida or Georgia in 2.3-4.7 days. $\mathrm{CO}_{2}$ concentrations within pallets at the beginning and end of transport were highest $(11 \%$ to $16 \%)$ in the sealed Tectrol system and relatively low $(0.06 \%$ to $0.30 \%)$ in the open $\mathrm{CO}_{2}$ West, PEAKfresh, and PrimePro cover systems. Relative to noncovered control fruit, which lost $0.8 \%$ fresh weight during shipment, the pallet covers reduced the transport-related weight loss by $38 \%$ to $52 \%$. The incidence of fruit decay was low $(1.0 \%$ to $1.4 \%)$ after transport but increased substantially following a 2 -day shelf life at $68{ }^{\circ} \mathrm{F}$. However, fruit from the Tectrol pallets exhibited significantly less decay (36\%) after shelf life than the $\mathrm{CO}_{2}$ West (39\%), noncovered control (41\%), PrimePro (42\%), and PEAKfresh (43\%) pallets. Fruit sensory quality was unaffected by the different pallet cover systems. Our findings show that transporting strawberries in the sealed Tectrol pallet cover system, in which $\mathrm{CO}_{2}$ concentrations were elevated to $11 \%$ to $16 \%$, was most effective in complementing current low temperature management practices to maintain fruit quality.

$\mathrm{T}$ The cultivated strawberry is a popular fruit worldwide with desirable flavor, texture, and visual appeal. In the United States, the value of total strawberry production was $\$ 2.2$ billion in 2010 [U.S. Department of Agriculture (USDA), 2011]. California accounts for $90 \%$ of national production. Fresh fruit are typically transported by refrigerated

We acknowledge TransFresh, Corp., and the U.S. Department of Agriculture NIFA Specialty Crops Research Initiative Award \#2009-51181-05783 for financial support. We also thank Dole Food Company, Inc., and Naturipe Farms for donating fruit, $\mathrm{CO}_{2}$ West, Inc., Destiny Packaging, Inc., PEAKfresh USA, and TransFresh, Corp. for supplying pallet cover systems, and Winn-Dixie Stores, Inc., and The Kroger Co. for assistance with transport shipments.

${ }^{1}$ Department of Plant Sciences, University of California, One Shields Avenue, Davis, CA 95616

${ }^{2}$ Horticultural Sciences Department, University of Florida, IFAS, Gainesville, FL 32611

${ }^{3}$ Food Science and Human Nutrition Department, University of Florida, IFAS, Gainesville, FL 32611

${ }^{4}$ Corresponding author. E-mail: ajmacnish@ucdavis. edu. truck trailers up to 3000 miles from growing areas to markets throughout North America (Mitcham and Mitchell, 2002). Strawberry fruit are a highly perishable commodity, and shipment at low temperature (i.e., $32{ }^{\circ} \mathrm{F}$ ) is critical for maintaining postharvest quality (Maxie et al., 1959).

The shelf life of strawberry fruit is often limited by their high rates of respiration, softening, and water loss (Kader, 1991). Fruit are also very susceptible to mechanical damage and decay (Sommer et al., 1973). Botrytis cinerea and Rhizopus stolonifer, the causal agents of gray mold and rhizopus rot, respectively, are the main pathogenic fungi to infect strawberry fruit (Maas, 1998; Wells, 1970). With gray mold, infection often begins in the field when the pathogen colonizes senescing flower petals and grows into the fruit (Powelson, 1960). The infection typically remains latent until fruit are exposed to favorable conditions such as physical wounding, high temperature, and high relative humidity (RH) that are sometimes encountered during postharvest handling (Sommer et al., 1973). Symptoms of disease are usually first visualized as light brown lesions on the fruit surface (Maas, 1998). These lesions eventually enlarge and become covered by masses of gray to tan-colored fungal mycelium and spores that render fruit unmarketable.

The application of chemical fungicides and proper cultural practices (e.g., field sanitation) during strawberry production have long been relied on to control fungal pathogens (Maas, 1998). Thereafter, nonchemical treatment strategies are typically used to control fruit decay during postharvest handling. For example, prompt (i.e., within $\mathrm{l}$ h of harvest) precooling and maintenance of fruit at low temperature during postharvest operations is widely recommended to slow metabolic reactions associated with fruit senescence and pathogen development (Maxie et al., 1959; Sommer et al., 1973). Exposure to a modified atmosphere (MA) of elevated $\mathrm{CO}_{2}$, reduced oxygen $\left(\mathrm{O}_{2}\right)$, or both can also retard the growth of fungal pathogens (Brooks, 1932; Couey et al., 1966; Couey and Wells, 1970). These fungistatic atmospheres complement proper temperature management in reducing decay, although the additive benefits are reportedly modest below $5{ }^{\circ} \mathrm{C}$ because fungal growth is already suppressed at these low temperatures (Harvey et al., 1966; Sommer et al., 1973).

Shipping and storing strawberries in a MA at low temperature is widely practiced by commercial operators in the United States to reduce decay and

\begin{tabular}{llll}
\hline $\begin{array}{l}\text { Units } \\
\begin{array}{l}\text { To convert U.S. to SI, } \\
\text { multiply by }\end{array}\end{array}$ & U.S. unit & SI unit & $\begin{array}{l}\text { To convert SI to U.S., } \\
\text { multiply by }\end{array}$ \\
\hline 2.54 & inch(es) & $\mathrm{cm}$ & 0.3937 \\
25.4 & inch $(\mathrm{es})$ & $\mathrm{mm}$ & 0.0394 \\
$\left({ }^{\circ} \mathrm{F}-32\right) \div 1.8$ & ${ }^{\circ} \mathrm{F}$ & ${ }^{\circ} \mathrm{C}$ & $\left(1.8 \times{ }^{\circ} \mathrm{C}\right)+32$ \\
$\Delta{ }^{\circ} \mathrm{F} \div 1.8$ & $\Delta^{\circ} \mathrm{F}$ & $\Delta^{\circ} \mathrm{C}$ & $1.8 \times \Delta{ }^{\circ} \mathrm{C}$
\end{tabular}


maintain fruit quality (Kader, 2002). The most commonly used MA system, Tectrol (TransFresh, Corp., Salinas, $\mathrm{CA}$ ), involves enclosing an entire pallet of strawberries in a plastic cover that is sealed to a plastic sheet on the pallet base. A partial vacuum is established within the pallet and $\mathrm{CO}_{2}$ gas is then injected to establish an atmosphere of $10 \%$ to $15 \% \mathrm{CO}_{2}$ and $5 \%$ to $10 \% \mathrm{O}_{2}$ (Harvey et al., 1980; Kader, 1991). An alternative MA system, $\mathrm{CO}_{2}$ West $\left(\mathrm{CO}_{2}\right.$ West, San Luis Obispo, $\left.\mathrm{CA}\right)$, uses pads containing sodium bicarbonate and citric acid that react with water vapor to liberate $\mathrm{CO}_{2}$ inside the plastic pallet cover (Finnegan and Boldt, 2007), which is open at the pallet base. Two additional pallet cover systems, PEAKfresh (PEAKfresh USA, Lake Forest, CA) and PrimePro (Destiny Packaging, Monterey, CA), simply involve placing a plastic cover over pallets. Both of these MA systems remain open at the pallet base and rely on strawberry fruit respiration to increase $\mathrm{CO}_{2}$ and decrease $\mathrm{O}_{2}$ concentrations.

The pallet cover systems listed above are claimed to extend the postharvest life and enhance the quality of strawberry fruit. However, there is limited publicly available data comparing the efficacy of these systems. In the present study, we evaluated the capacity of the four proprietary pallet cover systems $\left(\mathrm{CO}_{2}\right.$ West, PEAKfresh, PrimePro, and Tectrol) to reduce decay and maintain quality of strawberry fruit during and after six transcontinental shipments from Watsonville, CA to Atlanta, GA or Jacksonville, FL. Fruit were also evaluated after a 2 -d simulated retail display life to determine if there were residual effects of the intransit treatments.

\section{Materials and methods}

Plant material. 'Albion' strawberry fruit were harvested at commercial maturity (red color on $\geq 90 \%$ of fruit surface) from farms near Watsonville, CA. 'Albion' is a popular cultivar, and accounted for $58 \%$ of all commercial strawberry production in the Watsonville, CA, district in 2011 (California Strawberry Commission, 2012). A commercial crew placed fruit into $\mathrm{l} \mathrm{lb}$ capacity plastic vented clamshells in the field as per standard practice. Eight clamshells were packed into a fiberboard flat. Six flats were assembled as a single layer on a $40 \times$ 48 -inch wood pallet base. A total of 18 layers of six flats each were then stacked onto the pallet. Pallets were transported by a flatbed truck to one of two cooling facilities in Watsonville, CA. Fruit were transferred to a cooler for forced-air cooling within $2 \mathrm{~h}$ of harvest.

Sample preparation. Palletized fruit from the same farm were transferred to a $32{ }^{\circ} \mathrm{F}$ cold room and forced-air cooled for $1.5 \mathrm{~h}$ to a pulp temperature of $32-35{ }^{\circ} \mathrm{F}$, depending upon the cooling and shipping facility. Both of the cooling facilities were maintained at $32{ }^{\circ} \mathrm{F}$ and all sample work was completed in these cold rooms to prevent fruit warming. Four flats were removed from each pallet at layers 4, 8, 10, and 14. Clamshells within the sampled flats were rearranged in a completely randomized design and individually labeled. A datalogger (HOBO U12-013; Onset Computers Corp., Bourne, MA) that recorded temperature and $\mathrm{RH}$ was inserted into a randomly selected clamshell at layers 4,10 , and 14 in the first replicate pallet of each treatment, and at layer 10 in the remaining replicate pallets (Fig. 1). A single fruit was removed from these clamshells to accommodate each datalogger. Dataloggers were fitted with an internal temperature and $\mathrm{RH}$ sensor with an accuracy of $\pm 0.7^{\circ} \mathrm{F}$ and $\pm 2.5 \% \mathrm{RH}$, respectively, plus an external needle style temperature probe that was inserted into an individual fruit located in the center of the selected clamshell. The calibration of dataloggers was validated by placing each needle probe into an ice water bath before shipment. Sample flats were then placed back into 12 test pallets. Four additional flats were sampled from the load and transported to the laboratory at the University of California, Davis, CA, within $3 \mathrm{~h}$ at $41^{\circ} \mathrm{F}$ for intial evaluation.

Pallet treatments. Four proprietary plastic pallet covers $\mathrm{CO}_{2}$ West, PEAKfresh, PrimePro, and Tectrol were placed over the palletized fruit within the cold room according to the manufacturers' instructions. For the $\mathrm{CO}_{2}$ West treatment, two absorbent pads containing sodium bicarbonate and citric acid that generate $\mathrm{CO}_{2}$ were placed on the top layer of flats within each cover (Finnegan and Boldt, 2007). For the Tectrol treatment, the cover was sealed to a plastic sheet on each pallet base with adhesive tape, a partial vacuum was established, and pressurized $\mathrm{CO}_{2}$ gas was then injected inside to create an atmosphere of $\approx 15 \% \mathrm{CO}_{2}$ (Kader, 1991). The systems other than Tectrol remained open at the base. Additional pallets not wrapped in plastic covers served as the control. Pallets were held in the $32^{\circ} \mathrm{F}$ coolroom for $3-6 \mathrm{~h}$

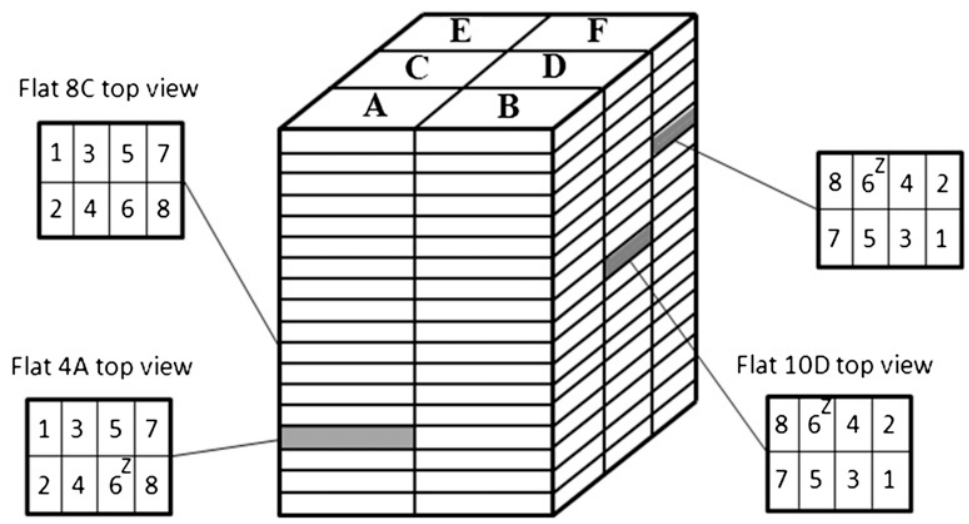

Fig. 1. A diagram showing a side view of a strawberry pallet (center) that consisted of 18 layers of six (A, B, C, D, E, F) fiberboard flats each, and top views of the four flats $(4 \mathrm{~A}, 8 \mathrm{C}, 10 \mathrm{D}, 14 \mathrm{~F})$ containing eight clamshells of fruit that were sampled for evaluation. A datalogger (HOBO U12-013; Onset Computers Corp., Bourne, MA) that recorded temperature and relative humidity was inserted into the sixth clamshell at layers $4 \mathrm{~A}, 10 \mathrm{D}$, and $14 \mathrm{~F}$ in the first replicate pallet of each treatment, and at layer $10 \mathrm{D}$ in the remaining replicate pallets. The $\mathrm{CO}_{2}$ concentration was also quantified within the sixth clamshell at layer $10 \mathrm{D}$ in two replicate $\mathrm{CO}_{2}$ West $\left(\mathrm{CO}_{2}\right.$ West, San Luis Obispo, CA) pallets during shipments 5 and 6 using $\mathrm{CO}_{2}$ dataloggers (Pac 7000; Drager, Lubeck, Germany); ${ }^{\mathrm{z}}$ indicates the position of dataloggers in clamshell number 6. 
before loading onto the refrigerated trailer for shipment.

Shipment. The 12 test pallets were loaded into a solid-walled refrigerated truck trailer equipped with air-ride suspension in a completely randomized design. An additional 12 pallets of precooled strawberries were loaded into the trailer to ensure a full load. The pallets were transported to a distribution center (DC) either near Atlanta, GA or Jacksonville, FL in 2.3$4.7 \mathrm{~d}$ depending upon the particular shipment (Table 1). The shorter transit times corresponded to shipments with two truck drivers who rotated driving shifts. Six shipments were completed between Aug. 2009 and Sept. 2010 (Table 1). Upon arrival, pallet covers were removed and the labeled clamshells were retrieved. These clamshells were transported to the University of Florida in Gainesville in an air-conditioned $\left(68^{\circ} \mathrm{F}\right)$ car within 2-6 h. Clamshells were maintained at $68^{\circ} \mathrm{F}$ and $60 \% \mathrm{RH}$ for $2 \mathrm{~d}$ to simulate unrefrigerated retail display (Nunes et al., 2009).

Evaluation of PALlet atMoSPHERES. $\mathrm{CO}_{2}$ and $\mathrm{O}_{2}$ concentrations in each pallet were quantified with a Bridge $\mathrm{CO}_{2} / \mathrm{O}_{2}$ gas analyzer (model 900141; Bridge Analyzers, Alameda, CA). Air samples were taken within $30 \mathrm{~min}$ of applying the pallet cover systems and again upon arrival at the DC. Briefly, a 25-gauge hypodermic needle (Becton Dickinson \& Co., Franklin Lakes, NJ) connected to the analyzer was inserted through one side wall of each pallet cover at $100 \mathrm{~cm}$ from the pallet base and air was withdrawn. Air samples were also collected from a similar position for the noncovered control pallets. The calibrated analyzer was verified to be within $\pm 4 \%$ accuracy of authentic $\mathrm{CO}_{2}$ and $\mathrm{O}_{2}$ gas standards (Matheson Tri-Gas, Newark, CA). A piece of adhesive tape was used to close each sampling hole in the covers. We also measured $\mathrm{CO}_{2}$ concentrations within a selected clamshell at layer 10 in two $\mathrm{CO}_{2}$ West pallets during shipments 5 and 6 using $\mathrm{CO}_{2}$ dataloggers (Pac 7000; Drager, Lubeck, Germany) (Fig. 1). The accuracy of the $\mathrm{CO}_{2}$ dataloggers was validated as described above for the $\mathrm{CO}_{2}$ and $\mathrm{O}_{2}$ analyzer.

Fruit Quality evaluation. One clamshell from each sample flat was weighed at the beginning and end of shipment and again after a 2 -d shelf life at $68^{\circ} \mathrm{F}$ to enable calculation of weight loss. The quality of all fruit within two replicate clamshells per sample flat was determined upon arrival at laboratory in Gainesville and again after the 2-d shelf life. Each clamshell contained $\approx 20$ fruit each. The overall clamshell quality was assessed using the following rating score: $\mathrm{l}=$ visible fungal decay on $\geq 10 \%$ of fruit, 3 = serious water loss, softening, water soaking, and slight evidence of fungal mycelia, 5 = lacks sheen, has some water soaked spots because of bruising and incipient decay, 7 = slightly dull appearance, $9=$ shiny appearance, turgid, and pleasant aroma. Fruit were then removed from the two selected clamshells per flat and rated individually for skin gloss using the USDA inspection criteria: 1 = bright, $2=$ fairly bright, $3=$ dull (USDA, 1975). Fruit exhibiting poor color (i.e., greater than $90 \%$ red) and visible symptoms of decay were recorded as a percentage of the initial number of fruit in a treatment (USDA, 1975).
Identification of gray mold was confirmed using a Botrytis QuickStix kit (model AS049OR; EnviroLogix, Portland, ME) (Meyer and Dewey, 2000 ). After reviewing the decay incidence data from shipments 1,2 , and 3 , we extended our evaluations to include assessment of the severity of decay for individual fruit in shipments 4,5 , and 6 using the following subjective rating score: $0=$ no visible decay, $\mathrm{l}$ = slight brown discoloration, $2=$ moderate brown discoloration, 3 = slight mycelial growth, $4=$ moderate mycelial growth, $5=$ extensive sporulation. Fruit firmness was measured on opposite sides of five replicate strawberries in each sample clamshell using an Ametek penetrometer (Mansfield \& Green Division, Largo, FL) mounted on a drill press and fitted with a 3-mm-diameter tip. The surface color of five replicate fruit in each sample clamshell from shipments 1, 2, and 3 was determined with a handheld tristimulus reflectance colorimeter (model CR-300; Minolta, Osaka, Japan).

FRUIT SENSORY ANALYSIS. In shipments 4,5 , and 6 , fruit were selected at random from the sample clamshells upon arrival to the laboratory in Gainesville and held at $32{ }^{\circ} \mathrm{F}$ for $16 \mathrm{~h}$. They were then rinsed in distilled water, air-dried, and placed into individually labeled plastic containers at $68^{\circ} \mathrm{F}$. Within $3 \mathrm{~h}$ of removal from $32^{\circ} \mathrm{F}$, duplicate samples from each pallet treatment were presented to a consumer panel consisting of 97 100 people $(40 \%$ male, $60 \%$ female, $84 \%$ between the ages of $18-29$ years), depending upon the particular shipment. Evaluations were completed in private booths where unsalted crackers

Table 1. The rate of temperature increase inside vented clamshells containing 'Albion' strawberry fruit during six separate refrigerated truck shipments from Watsonville, CA to Jacksonville, FL (shipments 1, 2, 3, 5) or Atlanta, GA (shipments 4, 6). The clamshells were palletized and cooled, covered within four $\left[\mathrm{CO}_{2}\right.$ West $\left(\mathrm{CO}_{2}\right.$ West, San Luis Obispo, CA), PEAKfresh (PEAKfresh USA, Lake Forest, CA), PrimePro (Destiny Packaging, Monterey, CA), and Tectrol (TransFresh, Corp., Salinas, CA)] proprietary pallet cover systems, and transported to the distribution centers. Noncovered pallets acted as the control.

\begin{tabular}{|c|c|c|c|c|c|c|c|}
\hline \multirow[b]{2}{*}{ Shipment no. } & \multirow[b]{2}{*}{ Harvest date } & \multirow[b]{2}{*}{ Shipment duration (d) } & \multicolumn{5}{|c|}{ Increase in temp $\left[\text { mean } \pm \mathrm{SE}\left({ }^{\circ} \mathrm{F} / \mathrm{d}\right)\right]^{\mathrm{z}}$} \\
\hline & & & Control & $\mathrm{CO}_{2}$ West & PEAKfresh & PrimePro & Tectrol \\
\hline 1 & 31 Aug. 2009 & 2.3 & $0.4 \pm 0.2 b^{y}$ & $1.7 \pm 0.1 \mathrm{a}$ & $1.5 \pm 0.2 \mathrm{a}$ & $1.9 \pm 0.1 \mathrm{a}$ & $1.5 \pm 0.0 \mathrm{a}$ \\
\hline 3 & 6 Oct. 2009 & 2.4 & $1.1 \pm 0.2 \mathrm{~b}$ & $1.9 \pm 0.5 \mathrm{ab}$ & $2.0 \pm 0.3 \mathrm{ab}$ & $2.4 \pm 0.3 \mathrm{a}$ & $1.8 \pm 0.0 \mathrm{ab}$ \\
\hline 4 & 4 June 2010 & 4.7 & $0.0 \pm 0.0 \mathrm{~b}$ & $1.5 \pm 0.1 \mathrm{a}$ & $1.6 \pm 0.1 \mathrm{a}$ & $1.2 \pm 0.2 \mathrm{a}$ & $1.4 \pm 0.2 \mathrm{a}$ \\
\hline 5 & 10 July 2010 & 3.6 & $0.9 \pm 0.3 c$ & $1.3 \pm 0.3 \mathrm{bc}$ & $2.0+0.1 \mathrm{a}$ & $2.2 \pm 0.1 \mathrm{a}$ & $1.9 \pm 0.1 \mathrm{ab}$ \\
\hline
\end{tabular}

${ }^{2}$ Data are representative of four (control, PEAKfresh, PrimePro) or five $\left(\mathrm{CO}_{2}\right.$ West, Tectrol) replicate dataloggers; $\Delta{ }^{\circ} \mathrm{F} \div 1.8=\Delta{ }^{\circ} \mathrm{C}$.

y Data for each shipment followed by different letters are significantly different based on the least significant difference test at $P=0.05$ 
and distilled water were provided to participants. Panelists evaluated different attributes of fruit sensory quality (firmness, overall acceptability, overall appearance, strawberry flavor, sweetness) using a 9-point hedonic scale $(\mathrm{l}=$ dislike extremely, $9=$ like extremely) and were invited to provide supporting comments.

EXPERIMENTAL DESIGN AND DATA ANALYSIs. Fruit for each shipment were selected from the same farm to decrease the variability associated with different cultural practices. Three replicate pallets were used for the $\mathrm{CO}_{2}$ West and Tectrol cover systems, while two replicate pallets were assigned to the PEAKfresh, PrimePro, and noncovered control treatments. Six separate shipments were completed. The fruit in eight replicate clamshells (two clamshells $\times$ four flats) per pallet were sampled after shipment and a 2 -d shelf life for the determination of fruit color, decay, firmness, gloss, and overall quality. Except where otherwise decribed, data for all six shipments were pooled and are presented as means \pm standard errors. Disease incidence and weight loss percentage data were arcsine-square root transformed to approximate a normal distribution for analysis of variance (ANOVA). Data were analyzed as one way ANOVAs using the generalized linear model procedure of SAS (version 9.1; SAS Institute, Cary, NC). When significant differences $(P \leq 0.05)$ occurred among the treatments, the least significant difference test at $P=0.05$ was used to separate the means.

\section{Results and discussion}

SHIPMENT TEMPERATURE AND RELATIVE HUMIDITY. The air temperature inside instrumented clamshells within the noncovered control pallets, which most closely reflected the truck trailer temperature, varied considerably among the six transcontinental shipments (Fig. 2). During shipments 1 and 4, the temperature within control clamshells remained a relatively stable $33-35^{\circ} \mathrm{F}$ and $34-35^{\circ} \mathrm{F}$, respectively, for the entire duration of refrigerated transport. In contrast, in shipments $2,3,5$, and 6 , the temperature increased from $32-35^{\circ} \mathrm{F}$ at loading to $35-39^{\circ} \mathrm{F}$ upon arrival at the DC. These ranges of transport temperatures are similar to those reported over 30 years ago for truck shipments of strawberries from California to New York

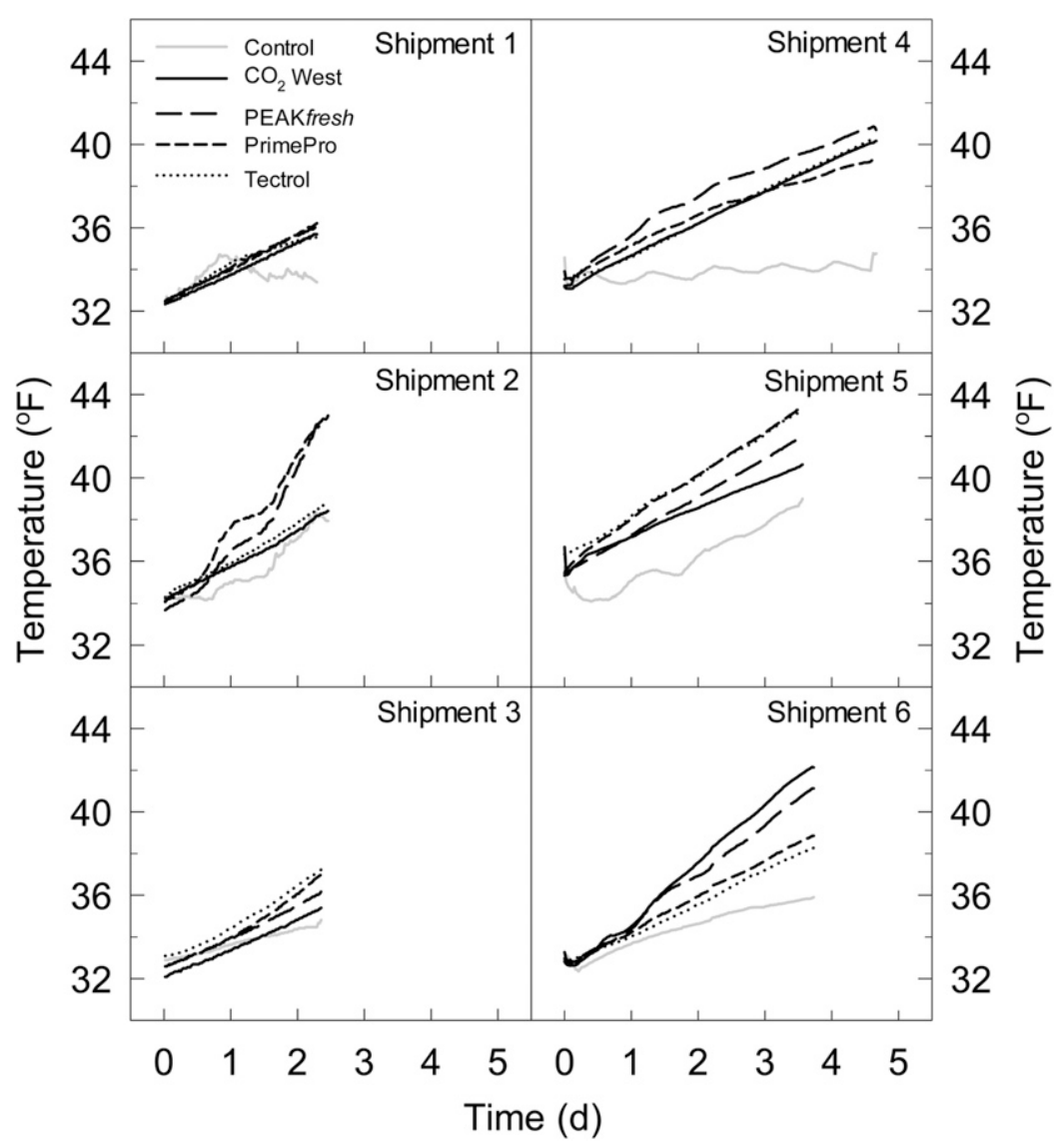

Fig. 2. Changes in air temperature inside vented clamshells containing 'Albion' strawberry fruit during six separate refrigerated truck shipments from Watsonville, CA to Jacksonville, FL (shipments $1,2,3,5$ ) or Atlanta, GA (shipments 4, 6). The clamshells were palletized within four $\left[\mathrm{CO}_{2}\right.$ West $\left(\mathrm{CO}_{2}\right.$ West, San Luis Obispo, CA), PEAKfresh (PEAKfresh USA, Lake Forest, CA), PrimePro (Destiny Packaging, Monterey, CA), and Tectrol (TransFresh, Corp., Salinas, CA)] proprietary pallet cover systems. Noncovered pallets acted as the control. Data are representative of four (control, PEAKfresh, PrimePro) or five $\left(\mathrm{CO}_{2}\right.$ West, Tectrol) replicate dataloggers; $\left({ }^{\circ} \mathrm{F}-32\right) \div 1.8={ }^{\circ} \mathrm{C}$.

(Harvey et al., 1980). Given that all six shipments were delivered direct from the cooling and shipping facilities in Watsonville, CA, to the DCs without opening the trailer doors, the rise in temperature during shipments indicates that the refrigerated trailers were unable to maintain the recommended $32{ }^{\circ} \mathrm{F}$ for strawberry transport (Maxie et al., 1959) because of either insufficient refrigeration capacity or poor air circulation around the product.

The air temperature inside the covered pallets increased steadily during all six shipments from $32-35^{\circ} \mathrm{F}$ at loading to $35-43{ }^{\circ} \mathrm{F}$ upon arrival at the DC (Fig. 2). When averaged across the six shipments, the air temperature inside $\mathrm{CO}_{2}$ West, PEAKfresh, PrimePro, and Tectrol covered pallets increased by $1.7,1.9,1.9$, and $1.7^{\circ} \mathrm{F}$ per day of transport, respectively (Table 1 ).
This steady increase in temperature within the covered pallets was significantly greater than in noncovered control pallets, in line with previous reports by Harvey et al. (1980) and Pelletier et al. (2011). It probably reflects the buildup of heat from fruit respiration and a low rate of heat transfer through the plastic pallet covers (Harvey, 1982). Overall, there were no significant differences between the clamshell air and fruit tissue temperatures during transport (data not shown). The air temperature also seldom varied by more than $2{ }^{\circ} \mathrm{F}$ at the three sampling positions (i.e., layers $4,10,14$ ) within pallets (data not shown).

The $\mathrm{RH}$ inside clamshells in the noncovered control pallets increased during all six shipments from $77 \%$ to $90 \%$ at loading to $93 \%$ to $96 \%$ upon 
arrival at the DC (Fig. 3). The increase in $\mathrm{RH}$ was most rapid during the first $24 \mathrm{~h}$ of transport. Placing $\mathrm{CO}_{2}$ West, PEAKfresh, and PrimePro covers over pallets generally enhanced this initial rise in $\mathrm{RH}$ by $1 \%$ to $5 \%$. In contrast, the RH in the closed Tectrol pallets was $4 \%$ to $11 \%$ lower at loading relative to the noncovered controls in association with the injection of dry compressed $\mathrm{CO}_{2}$ gas (Fig. 3; Nunes et al., 1995b). Thereafter, the RH inside the Tectrol pallets increased at rates consistent with the noncovered control and covered pallet systems. When averaged across the entire duration of all six shipments, the $\mathrm{RH}$ inside clamshells was 92\%, 93\%, 93\%, $93 \%$, and $89 \%$ in the noncovered control, $\mathrm{CO}_{2}$ West, PEAKfresh, PrimePro, and Tectrol pallets, respectively. There were no consistent differences in levels of $\mathrm{RH}$ inside clamshells at the three sampling positions within pallets (data not shown).

Pallet cover atmosphere. $\mathrm{CO}_{2}$ concentrations were always highest inside the Tectrol pallet covers at the beginning $(9.5 \%$ to $34.4 \%)$ and end (1.3\% to $24.8 \%)$ of each shipment (Table 2). Our findings are consistent with a previous report by Harvey et al. (1980) in which $\mathrm{CO}_{2}$ levels inside Tectrol pallets containing precooled strawberries varied from $4 \%$ to $26 \%$ during a 4-d refrigerated truck shipment. The overall decrease in $\mathrm{CO}_{2}$ levels during transport was presumably due to gradual diffusion through the Tectrol covers, an incomplete initial seal around the pallet base, and/or the development of holes in covers arising from rough handling (Harvey, 1982; Kader, 2002). In all other covered

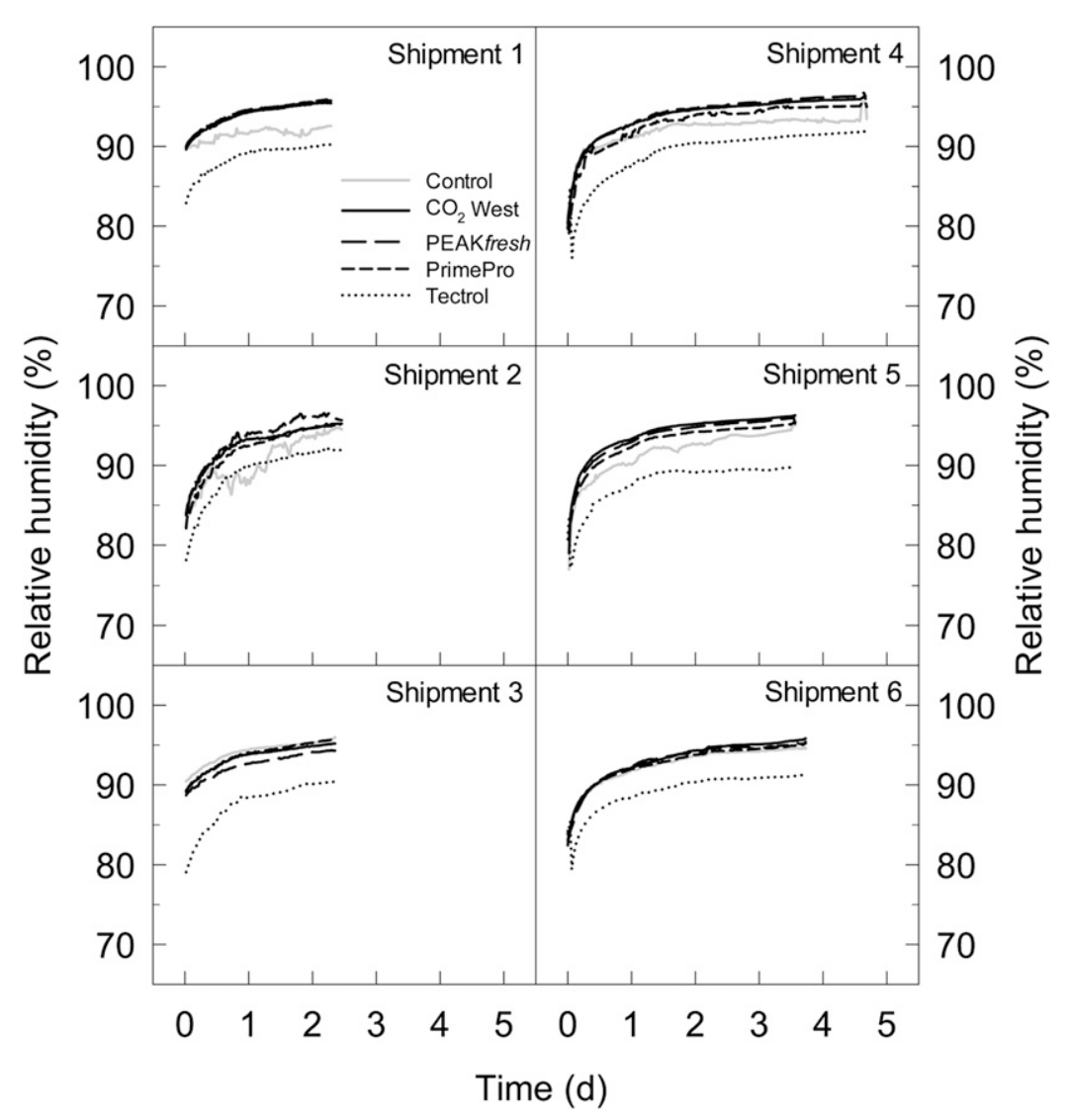

Fig. 3. Changes in the relative humidity inside vented clamshells containing 'Albion' strawberry fruit during six separate refrigerated truck shipments from Watsonville, CA to Jacksonville, FL (shipments 1, 2, 3, 5) or Atlanta, GA (shipments 4,6). The clamshells were palletized within four $\left[\mathrm{CO}_{2}\right.$ West $\left(\mathrm{CO}_{2} \mathrm{West}\right.$, San Luis Obispo, CA), PEAKfresh (PEAKfresh USA, Lake Forest, CA), PrimePro (Destiny Packaging, Monterey, CA), and Tectrol (TransFresh, Corp., Salinas, CA)] proprietary pallet cover systems. Noncovered pallets acted as the control. Data are representative of four (control, PEAKfresh, PrimePro) or five $\left(\mathrm{CO}_{2}\right.$ West, Tectrol) replicate dataloggers. pallet systems, the $\mathrm{CO}_{2}$ concentration was low (less than $0.15 \%$ ) at the beginning of shipment, and increased to $\approx 0.2 \%$ to $0.5 \%$ upon arrival at the DC (Table 2). $\mathrm{CO}_{2}$ levels were, however, found to increase to $1.2 \% \pm 0.1 \%$ $\mathrm{CO}_{2}$ (mean $\pm \mathrm{SE}, n=2$ ) after 9 and $12 \mathrm{~h}$ of transport within the $\mathrm{CO}_{2}$ West pallets when $\mathrm{CO}_{2}$ dataloggers were used in shipments 5 and 6 (data not shown). Because of a technical error with the $\mathrm{CO}_{2}$ dataloggers, we were unable to determine whether these higher $\mathrm{CO}_{2}$ levels were maintained in the $\mathrm{CO}_{2}$ West pallets for longer than $12 \mathrm{~h}$. Presumably, the accumulating water vapor within the pallet cover initiated this release of $\mathrm{CO}_{2}$ from the proprietary pad system. In any case, the increase in $\mathrm{CO}_{2}$ in the $\mathrm{CO}_{2}$ West system was transient since the $\mathrm{CO}_{2}$ concentration was only $0.2 \%$ to $0.5 \%$ upon arrival at the DC in all six shipments. $\mathrm{CO}_{2}$ concentrations in the uncovered control pallets were close to ambient (i.e., $0.03 \%$ ) at the beginning and end of each shipment. The $\mathrm{O}_{2}$ concentrations remained at ambient levels (21\%) in all pallets except for the Tectrol system in which it was reduced at the beginning $[18.8 \% \pm 0.3 \%$ (mean \pm SE, $n=18)]$ and end $[13.0 \% \pm 0.9 \%$ (mean \pm SE, $n=18$ )] of transport in association with the greatly elevated $\mathrm{CO}_{2}$ levels (data not shown). This moderate reduction in $\mathrm{O}_{2}$ concentration is similar to the levels measured inside sealed strawberry pallet covers enriched with $\mathrm{CO}_{2}$ during air shipment (Harvey et al., 1966, 1971).

Fruit Weight LOSs. Fruit in the noncovered control pallets lost $0.8 \% \pm 0.1 \%($ mean $\pm \mathrm{sE}, n=48)$ weight during the $2.5-5-\mathrm{d}$ refrigerated $\left(32-39^{\circ} \mathrm{F}\right)$ truck transport from California to Florida and Georgia (Fig. 4). When averaged across the six shipments, the pallet cover systems significantly reduced this transportrelated weight loss by $38 \%$ (PEAKfresh), $41 \%$ (PrimePro), 43\% ( $\mathrm{CO}_{2}$ West), and $52 \%$ (Tectrol). This low level of weight loss is consistent with published data from a 4-d refrigerated $\left(0.7-7.6{ }^{\circ} \mathrm{C}\right)$ truck shipment of 'San Juan' strawberries in Tectrol pallet covers (Pelletier et al., 2011). Moreover, it confirms the effectiveness of the plastic covers to act as a barrier to strawberry fruit water loss (Nunes et al., 1995a). The observation that fruit from the Tectrol pallets lost the least weight during shipment despite 
Table 2. Carbon dioxide $\left(\mathrm{CO}_{2}\right)$ concentrations inside four $\left[\mathrm{CO}_{2}\right.$ West $\left(\mathrm{CO}_{2}\right.$ West, San Luis Obispo, CA), PEAKfresh (PEAKfresh USA, Lake Forest, CA), PrimePro (Destiny Packaging, Monterey, CA), and Tectrol (TransFresh, Corp., Salinas, CA)] proprietary pallet cover systems containing palletized 'Albion' strawberry fruit at the beginning and end of six separate refrigerated truck shipments from Watsonville, CA to Jacksonville, FL (shipments 1, 2, 3, 5) or Atlanta, GA (shipments 4, 6). Noncovered pallets acted as the control.

\begin{tabular}{|c|c|c|c|c|c|}
\hline \multirow[b]{2}{*}{ Sample time } & \multicolumn{5}{|c|}{$\mathrm{CO}_{2}$ concn $[\operatorname{range}(\%)]^{\mathrm{z}}$} \\
\hline & Control & $\mathrm{CO}_{2}$ West & PEAKfresh & PrimePro & Tectrol \\
\hline \multicolumn{6}{|c|}{ Beginning of shipment } \\
\hline Shipment 2 & - & - & - & - & $9.50-16.00$ \\
\hline Shipment 3 & - & - & - & - & $10.00-12.50$ \\
\hline Shipment 4 & $0.03-0.03$ & $0.04-0.09$ & $0.06-0.07$ & $0.05-0.07$ & $14.20-19.10$ \\
\hline Mean $\pm S E^{x}$ & $0.05 \pm 0.01 \mathrm{~b}$ & $0.09 \pm 0.01 \mathrm{~b}$ & $0.06 \pm 0.01 \mathrm{~b}$ & $0.08 \pm 0.01 \mathrm{~b}$ & $15.74 \pm 1.33 \mathrm{a}$ \\
\hline \multicolumn{6}{|c|}{ End of shipment } \\
\hline Shipment 1 & - & $0.10-0.10$ & $0.20-0.30$ & $0.30-0.50$ & $9.60-12.20$ \\
\hline Shipment 2 & - & $0.10-0.20$ & $0.30-0.30$ & $0.20-0.20$ & $1.30-15.40$ \\
\hline Mean \pm SE & $0.03 \pm 0.00 \mathrm{~b}$ & $0.21 \pm 0.02 b$ & $0.30 \pm 0.04 b$ & $0.30 \pm 0.04 \mathrm{~b}$ & $10.81 \pm 1.06 \mathrm{a}$ \\
\hline
\end{tabular}

${ }^{2}$ Data range (minimum, maximum) are representative of two (control, PEAKfresh, PrimePro) or three $\left(\mathrm{CO}_{2}\right.$ West, Tectrol) replicate pallets.

${ }^{\mathrm{y}}$ Measurement was not performed.

${ }^{x}$ Column means $(n=6)$ followed by different letters are significantly different are significantly different based on the least significant difference test at $P=0.05$.

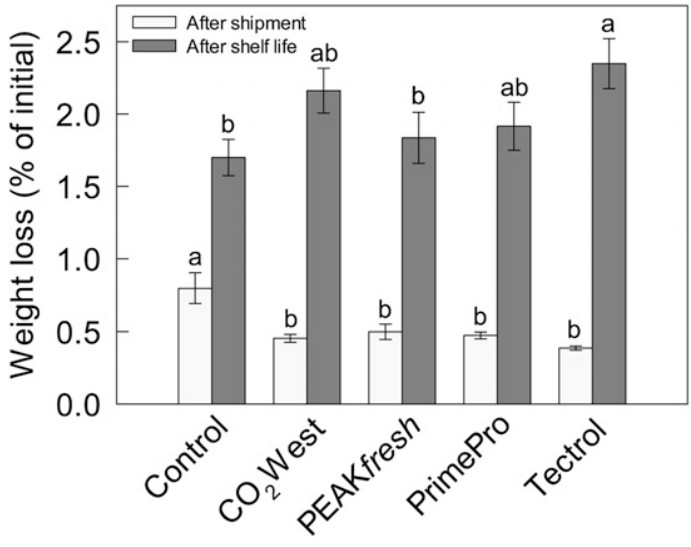

Fig. 4. Weight loss from 'Albion' strawberry fruit after refrigerated truck shipment from Watsonville, CA to Jacksonville, FL or Atlanta, GA, and following a 2-d shelf life at $68^{\circ} \mathrm{F}\left(20.0{ }^{\circ} \mathrm{C}\right)$. Fruit were transported inside vented clamshells that were palletized within four $\left[\mathrm{CO}_{2}\right.$ West $\left(\mathrm{CO}_{2}\right.$ West, San Luis Obispo, CA), PEAKfresh (PEAKfresh USA, Lake Forest, CA), PrimePro (Destiny Packaging, Monterey, CA), and Tectrol (TransFresh, Corp., Salinas, CA)] proprietary pallet cover systems. Noncovered pallets acted as the control. Data (mean $\pm \mathrm{SE}$ ) are representative of 48 (control, PEAKfresh, PrimePro) or $72\left(\mathrm{CO}_{2}\right.$ West, Tectrol) replicate clamshells from six shipments. Data followed by different letters are significantly different based on the least significant difference test at $P=0.05$.

being maintained at the lowest $\mathrm{RH}$ level may be a result of reduced rates of respiration in association with elevated $\mathrm{CO}_{2}$ atmospheres ( $\mathrm{Li}$ and Kader, 1989). Higher rates of weight loss (i.e., $1.7 \%$ to $2.3 \%$ ) were observed when the fruit were transferred to $68^{\circ} \mathrm{F}$ for a 2-d shelf life evaluation (Fig. 4).
Fruit transported in the Tectrol pallets lost significantly more weight during shelf life than control fruit. However, this weight loss was substantially less than the maximum (i.e., 6\%) tolerated before strawberry fruit are generally considered unmarketable (Robinson et al., 1975).
Fruit DeCAY INCIDENCE AND SEVERITY. There were no visible symptoms of decay on fruit at the beginning of shipment. Thereafter, the incidence of decay increased to low levels $(0.2 \%$ to $5.7 \%)$ at the end of shipment, and to relatively high levels ( $7 \%$ to $85 \%$ ) following a 2 -d shelf life at $68{ }^{\circ} \mathrm{F}$, depending upon the particular shipment. The low levels of decay that developed during low temperature $\left(32-43^{\circ} \mathrm{F}\right)$ shipment were not significantly reduced by any of the pallet cover systems tested in this study (Fig. 5). This observation corroborates earlier findings that elevated (e.g., 10\% to $20 \% \mathrm{CO}_{2}$ atmospheres do not enhance decay control at low (i.e., less than $5^{\circ} \mathrm{C}$ ) temperatures (Harvey et al., 1966, 1980; Sommer et al., 1973). However, fruit exposed to the relatively high $(11 \%$ to $16 \%) \mathrm{CO}_{2}$ levels in the Tectrol pallets exhibited significantly less decay after a 2 -d shelf life as compared with control fruit (Fig. 5 ). Long-term (e.g., 3-5 d) exposure to such MAs can carry over residual benefits into subsequent air storage (Harris and Harvey, 1973; Li and Kader, 1989), and this may explain why fruit transported in the Tectrol pallets displayed lower levels of decay during shelf life at $68^{\circ} \mathrm{F}$. While not significantly different from control 


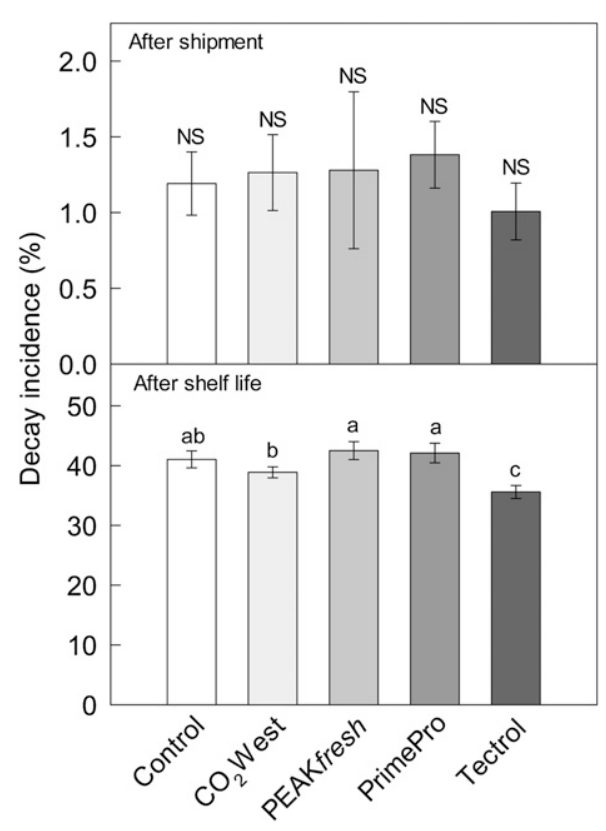

Fig. 5. Incidence of decay on 'Albion' strawberry fruit after refrigerated truck shipment from Watsonville, CA to Jacksonville, FL or Atlanta, GA, and following a 2-d shelf life at $68^{\circ} \mathrm{F}\left(20.0{ }^{\circ} \mathrm{C}\right)$. Fruit were transported inside vented clamshells that were palletized within four $\left[\mathrm{CO}_{2}\right.$ West $\left(\mathrm{CO}_{2}\right.$ West, San Luis Obispo, $\left.\mathrm{CA}\right)$, PEAKfresh (PEAKfresh USA, Lake Forest, CA), PrimePro (Destiny Packaging, Monterey, CA), and Tectrol (TransFresh, Corp., Salinas, CA)] proprietary pallet cover systems. Noncovered pallets acted as the control. Data (mean $\pm \mathrm{SE}$ ) are representative of 96 (control, PEAKfresh, PrimePro) or $144\left(\mathrm{CO}_{2}\right.$ West, Tectrol) replicate clamshells from six shipments. Data followed by different letters are significantly different based on the least significant difference test at $P=0.05$. NS indicates no significant difference between data.

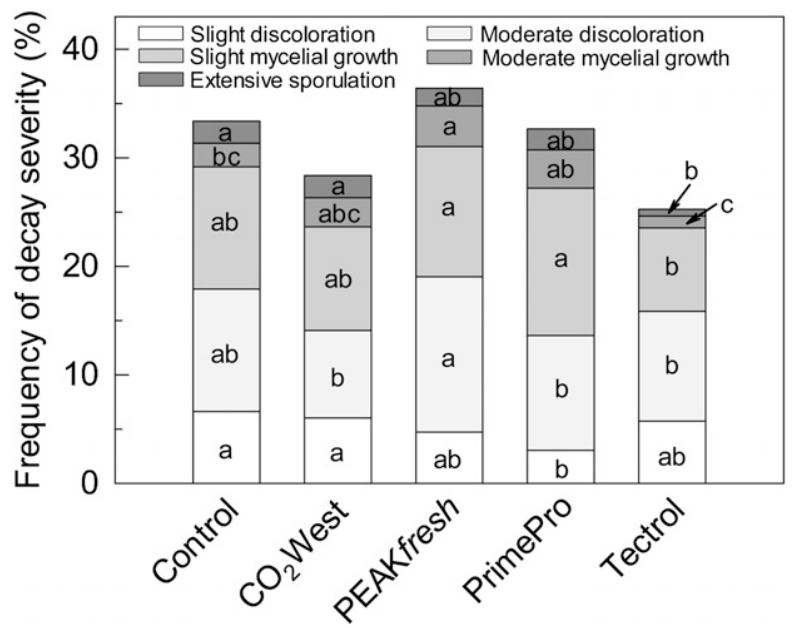

Fig. 6. Frequency of decay severity stages on individual 'Albion' strawberry fruit following a 2 -d shelf life at $68^{\circ} \mathrm{F}\left(20.0^{\circ} \mathrm{C}\right)$. Fruit in vented clamshells were palletized within four $\left[\mathrm{CO}_{2}\right.$ West $\left(\mathrm{CO}_{2}\right.$ West, San Luis Obispo, CA), PEAKfresh (PEAKfresh USA, Lake Forest, CA), PrimePro (Destiny Packaging, Monterey, CA), and Tectrol (TransFresh, Corp., Salinas, CA)] proprietary pallet cover systems. Noncovered pallets acted as the control. The fruit were transported by refrigerated truck from Watsonville, CA to Jacksonville, FL or Atlanta, GA before shelf life evaluation. Data (mean $\pm \mathrm{SE}$ ) are representative of fruit from 48 (control, PEAKfresh, PrimePro) or 72 ( $\mathrm{CO}_{2}$ West, Tectrol) replicate clamshells from three shipments (i.e., shipments $4,5,6$ ). Data within each decay severity category followed by different letters are significantly different based on the least significant difference test at $P=\mathbf{0 . 0 5}$. fruit, strawberries transported in the $\mathrm{CO}_{2}$ West pallets also displayed less decay after shelf life than those in the PEAKfresh and PrimePro passive MA systems. The variation in the level of decay for fruit from the different shipments was considerable; the incidence of decay on noncovered control fruit after shelf life was $82 \%, 37 \%, 28 \%, 35 \%$, $56 \%$, and $9 \%$ for shipments $1,2,3,4$, 5 , and 6 , respectively. This presumably reflects variation in preharvest fungal infection levels and the extent of mechanical damage during harvesting.

There were no consistent effects of the pallet cover systems on the severity of fungal decay on fruit immediately after shipment (data not shown). However, following the 2-d shelf life, fruit transported in the Tectrol pallets displayed significantly less decay at severity stages 3 and 4 (slight to moderate mycelial growth) than the PEAKfresh and PrimePro pallets (Fig. 6). Fruit sampled from the Tectrol pallets also exhibited a lower frequency of stage 5 infection (extensive sporulation) than strawberries from the control and $\mathrm{CO}_{2}$ West pallets following shelf life. This response could be attributed to the higher fungistatic $\mathrm{CO}_{2}$ levels maintained in the Tectrol pallets that have previously been shown to retard the growth and development of $B$. cinerea on strawberries (El-Kazzaz et al., 1983). In contrast, the severity of fruit decay after shelf life was not reduced in the other pallet cover systems in which low $(0.5 \%)$ $\mathrm{CO}_{2}$ levels were maintained (Fig. 6, Table 2). Most of the fungal decay was identified as B. cinerea.

Fruit Quality. Fruit firmness was largely maintained during shipment and the 2-d shelf life (data not shown). However, there were no consistent effects of the pallet cover systems on the firmness of fruit. Exposure to low (e.g., $\left.0{ }^{\circ} \mathrm{C}\right)$ temperatures, elevated (e.g., $4 \%$ to $24 \%$ ) $\mathrm{CO}_{2}$ concentrations, or both have previously been associated with the maintenance and even enhancement of fruit firmness during storage of selected strawberry cultivars (Harker et al., 2000; Harris and Harvey, 1973; Larsen and Watkins, 1995; Smith, 1992). The overall visual quality of fruit from each treatment decreased during shipment and shelf life (Fig. 7). This loss in quality represented an increase in decay and a decrease in fruit gloss (data not shown). When averaged overall six shipments, 


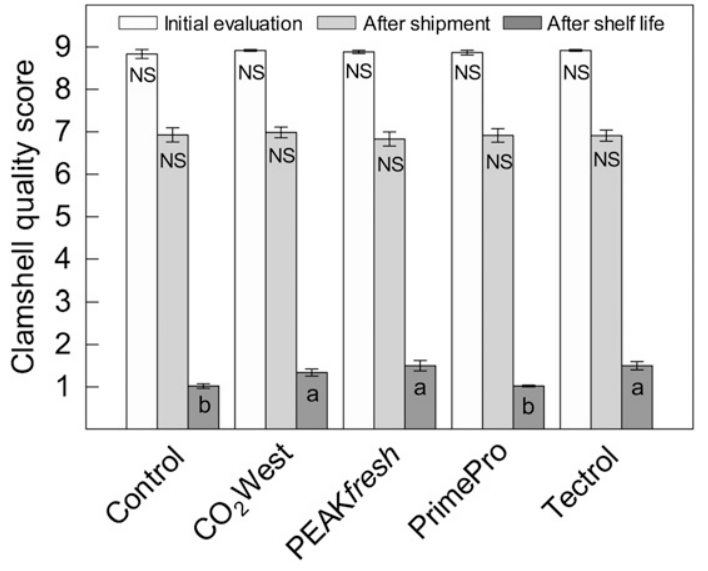

Fig. 7. Changes in the overall clamshell quality of 'Albion' strawberry fruit after refrigerated truck shipment from Watsonville, CA to Jacksonville, FL or Atlanta, GA, and following a 2-d shelf life at $68^{\circ} \mathrm{F}\left(20.0^{\circ} \mathrm{C}\right)$. Fruit were transported inside vented clamshells that were palletized within four $\left[\mathrm{CO}_{2}\right.$ West $\left(\mathrm{CO}_{2}\right.$ West, San Luis Obispo, CA), PEAKfresh (PEAKfresh USA, Lake Forest, CA), PrimePro (Destiny Packaging, Monterey, CA), and Tectrol (TransFresh, Corp., Salinas, CA)] proprietary pallet cover systems. Noncovered pallets acted as the control. Data $\left(\right.$ mean \pm SE) are representative of 96 (control, PEAKfresh, PrimePro) or $144\left(\mathrm{CO}_{2}\right.$ West, Tectrol) replicate clamshells from six shipments. Data followed by different letters are significantly different based on the least significant difference test at $P=$ 0.05. NS indicates no significant difference between data. Clamshell quality rating score: 1 = visible fungal decay on $\geq 10 \%$ of fruit, 3 = serious water loss, softening, water soaking, and slight evidence of fungal mycelia, 5 = lacks sheen, has some water soaked spots due to bruising and incipient decay, 7 = slightly dull appearance, $9=$ shiny appearance, turgid, and pleasant aroma.

the loss in quality after a 2 -d shelf life was greatest for fruit from the noncovered control and PrimePro pallets, and least for strawberries transported in the $\mathrm{CO}_{2}$ West, PEAKfresh, and Tectrol pallet cover systems (Fig. 7). The surface color of fruit displayed a darkened, less intense red coloration after transport and shelf life (data not shown) and presumably was a consequence of fruit weight loss and associated browning (Nunes et al., 1995b; Sacks and Shaw, 1993). There was, however, no significant effect of the pallet cover treatments on these changes in fruit color (data not shown). Several studies have shown that the exposure of strawberries to relatively high (e.g., greater than $15 \%) \mathrm{CO}_{2}$ concentrations during low temperature storage or transport can help maintain a light red skin color (Gil et al., 1997; Holcroft and Kader, 1999; Nunes et al., 1995b). The frequency of fruit that exhibited poor color (less than $90 \%$ red) after shipment and shelf life was also unaffected by the pallet cover system employed during transport (data not shown).

Fruit Sensory Quality. There were no significant differences in the sensory quality of fruit sampled from the different pallet systems at the end of shipments 4,5 , and 6 as judged by consumer sensory panels (data not shown). When averaged across all pallet treatments, the overall appearance $(6.9 \pm 0.1)$, acceptability $(7.0 \pm$ 0.1 ), firmness $(7.1 \pm 0.1)$, strawberry flavor $(6.9 \pm 0.1)$, and sweetness $(6.7 \pm$ 0.1 ) of fruit samples (mean \pm SE, $n=$ 1485 ) were all rated relatively high on the 9-point hedonic scale. Similarly, El-Kazzaz et al. (1983) reported that treatment with $15 \% \mathrm{CO}_{2}$ for $2 \mathrm{ld}$ at $3 .{ }^{\circ} \mathrm{C}$ did not affect the sweetness, sourness, and flavor intensity of strawberries relative to control (i.e., room air) fruit. However, exposure to MAs of ultralow (e.g., less than $0.25 \%) \mathrm{O}_{2}$ and/or high (e.g., greater than 20\%) $\mathrm{CO}_{2}$ are frequently associated with the development of off-flavors (i.e., acetaldehyde, ethyl acetate, ethanol volatiles) in strawberry fruit (e.g., Couey et al., 1966; Larsen and Watkins, 1995; Li and Kader, 1989; Watkins et al., 1999). In the current study, the sensory panels did not detect offflavors in any fruit, including strawberries from the Tectrol pallets that were shipped in atmospheres of elevated (e.g., $11 \%$ to $16 \%$ ) $\mathrm{CO}_{2}$ for $2.3-$ $4.7 \mathrm{~d}$. Given that the fruit were held in room air at $32{ }^{\circ} \mathrm{F}$ for $16-22 \mathrm{~h}$ after removal from the pallet cover systems to simulate retail handling, it is possible that off-flavors attributable to high $\mathrm{CO}_{2}$ exposure had devolved from fruit tissues before tasting. High $\mathrm{CO}_{2}-$ induced off-flavors in strawberry have been shown to decrease when the fruit are held in room air for $24 \mathrm{~h}$ at $20^{\circ} \mathrm{C}$ (Larsen and Watkins, 1995).

In conclusion, our findings show that transporting palletized strawberries within MA pallet cover systems can reduce the loss of fruit weight and associated visual quality (e.g., gloss) even at relatively low $\left(32-43^{\circ} \mathrm{F}\right)$ transcontinental shipment temperatures. Transporting fruit in the sealed $\mathrm{Tec}-$ trol pallet cover system, in which $\mathrm{CO}_{2}$ concentrations were elevated to $11 \%$ to $16 \%$, was most effective as it also significantly reduced decay development during subsequent simulated retail display. While our data highlight some statistically significant advantages of using strawberry pallet covers in combination with low temperature management, a cost-benefit analysis is recommended to reveal the true commercial value of each system.

\section{Literature cited}

Brooks, C. 1932. Effect of solid and gaseous carbon dioxide upon transit diseases of certain fruits and vegetables. U.S. Dept. Agr. Tech. Bul. 318.

California Strawberry Commission. 2012. Varieties and season information. 21 May 2012. <http://www.calstrawberry.com/ commission/varieties.asp $>$.

Couey, H.M., M.N. Follstad, and M. Uota. 1966. Low oxygen atmospheres for control of postharvest decay of fresh strawberries. Phytopathology 56:13391341.

Couey, H.M. and J.M. Wells. 1970. Low oxygen or high carbon dioxide atmospheres to control postharvest decay of fresh strawberries. Phytopathology 60: 47-49.

El-Kazzaz, M.K., N.F. Sommer, and R.J. Fortlage. 1983. Effect of different atmospheres on postharvest decay and quality of fresh strawberries. Phytopathology 73:282-285.

Finnegan, M.J. and W.L. Boldt. 2007. $\mathrm{CO}_{2}$ generating absorbent pads. U.S. Patent 7189666. U.S. Patent and Trademark Office, Washington, DC.

Gil, M.I., D.M. Holcroft, and A.A. Kader. 1997. Changes in strawberry anthocyanins 
and other polyphenols in response to carbon dioxide treatments. J. Agr. Food Chem. 45:1662-1667.

Harker, F.R., H.J. Elgar, C.B. Watkins, P.J. Jackson, and I.C. Hallett. 2000. Physical and mechanical changes in strawberry fruit after high carbon dioxide treatments. Postharvest Biol. Technol. 19: 139-146.

Harris, C.M. and J.M. Harvey. 1973. Quality and decay of California strawberries stored in $\mathrm{CO}_{2}$-enriched atmospheres. Plant Dis. Rptr. 57:44-46.

Harvey, J.M. 1982. $\mathrm{CO}_{2}$ atmospheres for truck shipments of strawberries, p. 359365. In: D.G. Richardson and M. Meheriuk (eds.). Controlled atmospheres for storage and transport of perishable agricultural commodities. Timber Press, Portland, OR.

Harvey, J.M., H.M. Couey, C.M. Harris, and F.M. Porter. 1966. Air transport of California strawberries: Factors affecting market quality in summer shipments 1965. U.S. Dept. Agr. Mktg. Res. Rpt. 751.

Harvey, J.M., C.M. Harris, and F.M. Porter. 1971. Air transport of California strawberries: Pallet covers to maintain modified atmospheres and reduce market losses. U.S. Dept. Agr. Mktg. Res. Rpt. 920 .

Harvey, J.M., C.M. Harris, W.J. Tietjen, and T. Seriol. 1980. Quality maintenance in truck shipments of Californian strawberries. Adv. Agr. Technol. AAT-W-12. U.S. Dept. Agr., Sci. Educ. Admin., Washington, DC.

Holcroft, D.M. and A.A. Kader. 1999. Carbon dioxide-induced changes in color and anthocyanin synthesis of stored strawberry fruit. HortScience 34:1244-1248.

Kader, A.A. 1991. Quality and its maintenance in relation to the postharvest physiology of strawberry, p. 145-152. In: A. Dale and J.J. Luby (eds.) The strawberry into the 21 st century. Timber Press, Portland, OR.

Kader, A.A. 2002. Modified atmospheres during transport and storage, p. 135-144. In: A.A. Kader (ed.). Postharvest technology of horticultural crops. 3rd ed. Univ. of Calif. Div. Agr. Natural Resources Publ. 3311.

Larsen, M. and C.B. Watkins. 1995. Firmness and concentrations of acetaldehyde, ethyl acetate and ethanol in strawberries stored in controlled and modified atmospheres. Postharvest Biol. Technol. $5: 39-50$

Li, C. and A.A. Kader. 1989. Residual effects of controlled atmospheres on postharvest physiology and quality of strawberries. J. Amer. Soc. Hort. Sci. 114: 629-634.

Maas, J.L. 1998. Compendium of strawberry diseases. 2nd ed. Amer. Phytopathol. Soc., St. Paul, MN.

Maxie, E.C., F.G. Mitchell, and A. Greathead. 1959. Studies on strawberry quality: High temperatures that may occur in harvesting and handling of strawberries influence the rate of fruit deterioration. California Agr. 13(2):11,16.

Meyer, U.M. and F.M. Dewey. 2000. Efficacy of different immunogens for raising monoclonal antibodies to Botrytis cinerea. Mycol. Res. 104:979-987.

Mitcham, E.J. and F.G. Mitchell. 2002. Postharvest handling systems: Small fruits, strawberries and cane berries, p. 364-370. In: A.A. Kader (ed.). Postharvest technology of horticultural crops. 3rd ed. Univ. Calif. Div. Agr. Natural Resources Publ. 3311.

Nunes, M.C.N., J.K. Brecht, S.A. Sargent, and A.M.M.B. Morais. 1995a. Effects of delays to cooling and wrapping on strawberry quality (cv. Sweet Charlie). Food Contr. 6:323-328.

Nunes, M.C.N., J.-P. Emond, M. Rauth, S. Dea, and K.V. Chau. 2009. Environmental conditions encountered during typical consumer retail display affect fruit and vegetable quality and waste. Postharvest Biol. Technol. 51:232-241.

Nunes, M.C.N., A.M.M.B. Morais, J.K. Brecht, and S.A. Sargent. 1995b. Quality of strawberries after storage in controlled atmospheres at above optimum storage temperatures. Proc. Florida State Hort. Soc. 108:273-278.
Pelletier, W., J.K. Brecht, M.C.N. Nunes, and J.-P. Emond. 2011. Quality of strawberries shipped by truck from California to Florida as influenced by postharvest temperature management practices. HortTechnology 21:482-493.

Powelson, R.L. 1960. Initiation of strawberry fruit rot caused by Botrytis cinerea. Phytopathology 50:491-494.

Robinson, J.E., K.M. Browne, and W.G. Burton. 1975. Storage characteristics of some vegetables and soft fruits. Ann. Appl. Biol. 81:399-408.

Sacks, E.J. and D.V. Shaw. 1993. Color change in fresh strawberry fruit of seven genotypes stored at $0{ }^{\circ} \mathrm{C}$. HortScience 28:209-210.

Smith, R.B. 1992. Controlled atmosphere storage of 'Redcoat' strawberry fruit. J. Amer. Soc. Hort. Sci. 117:260264.

Sommer, N.F., R.F. Fortlage, F.G. Mitchell, and E.C. Maxie. 1973. Reduction of postharvest losses of strawberry fruits from gray mold. J. Amer. Soc. Hort. Sci. 98: 285-288

U.S. Department of Agriculture. 1975. Strawberries and other berries: Shipping point and market inspection instructions. U.S. Dept. Agr., Agr. Mktg. Serv., Fruit Veg. Div., Fresh Products, Washington, DC.

U.S. Department of Agriculture. 2011. Non citrus fruits and nuts: 2010 Summary. 24 June 2012. <http://usda01.library. cornell.edu/usda/nass/NoncFruiNu// $2010 \mathrm{~s} / 2011 /$ NoncFruiNu-07-072011.pdf>.

Watkins, C.B., J.E. Manzano-Mendez, J.F. Nock, J. Zhang, and K.E. Maloney. 1999. Cultivar variation in response of strawberry fruit to high carbon dioxide treatments. J. Sci. Food Agr. 79:886890.

Wells, J.M. 1970. Modified atmosphere, chemical, and heat treatments to control postharvest decay of California strawberries. Plant Dis. Rptr. 54:431-434. 